This is the Accepted Manuscript version of: Wignell, P., O'Halloran, K. L., Tan, S., Lange, R., \& Chai, K. (2018). Image and text relations in ISIS materials and the new relations established through recontextualisation in online media. Discourse \& Communication, 12(5), 535-559. DOI: 10.1177/1750481318766938.

\title{
Image and text relations in ISIS materials and the new relations established through recontextualisation in online media
}

\author{
Peter Wignella, Kay L O’Halloranab, Sabine Tana, Rebecca Langeb and \\ Kevin Chaib
}

aSchool of Education, Curtin University, Perth, Western Australia

${ }_{b}$ Curtin Institute for Computation, Curtin University, Perth, Western Australia

\section{Abstract}

This study takes a systemic functional multimodal social semiotic approach to the analysis and discussion of image and text relations in two sets of data. First, patterns of contextualization of images and text in the online magazines Dabiq and Rumiyah, produced by the Islamic extremist organisation which refers to itself as Islamic State (referred to here as ISIS) are examined. The second data set consists of a sample of texts from Western online news and blog sites which include recontextualisations of images found in the first data set. A sample of examples of the use and re-use of images is discussed in order to identify patterns of similarity and difference when images and text are recontextualised. It is argued that the ISIS material tends to foreground the interpersonal metafunction in combination with the textual metafunction (i.e. the stance towards the content and the organization of the message for this purpose) while the other data set tends to foreground the ideational metafunction (the participants, processes and circumstances of what is being reported). These inferences indicate that further exploration of a larger data set is worth pursuing. Such studies would provide deeper insights helping to distinguish between online material which supports terrorism and that which opposes it, as well as facilitating the further development of multimodal social semiotic approaches to image and text relations. 
Keywords: social semiotics; multimodal discourse analysis; image and text relations; ISIS; jihad

\section{Introduction}

With the recapture of the city of Mosul in Iraq in July, 2017, and the fall of their 'capital', the city of Raqqa in Syria, in October, 2017, the ability of the Sunni Islamic extremist organisation known, among other acronyms, as ISIS, to continue its jihad by relatively orthodox military means in its heartlands was severely compromised. However, whether this impacts on the international terror operations of ISIS, its affiliates and sympathisers elsewhere is not known. Much of ISIS's global terror campaign is based on information distributed and redistributed through the Internet and social media (i.e. Web-based technologies and mobile devices). For example, recent issues of one of ISIS's flagship online magazines, Rumiyah, have presented explicit instructions on how sympathisers can commit 'lone wolf' acts of terror (e.g. Rumiyah Issues 2 and 3). These 'instructions' have often preceded terror attacks which have adopted the means described in Rumiyah (e.g. The attack at Ohio State University on November 28, 2016, which followed the release of Issue 3 of Rumiyah on November 11, 2016).

Even though the military threat of ISIS has been drastically curtailed, their propaganda campaign, which includes prolific amounts of material produced over a number of years, still continues. Today, even if the propaganda is compromised, there is a still a very substantial body of material which has accumulated on the Internet which is still readily accessible. For this reason, even if their 'army' is defeated their message continues, both in ISIS-produced materials and in parts of those materials which have been reused in mainstream and social media. 
ISIS has always been a prolific producer of propaganda material. This propaganda material has explicit goals, including propagating ISIS's agenda through clearly presenting and attempting to legitimise its world view and values (see Wignell, Tan and O'Halloran, 2016), inducing supporters and potential supporters to participate in their jihad (see Wignell, Tan and O'Halloran, 2017) and to maximise fear and disruption among people ISIS perceive to be their enemies. This material is typically multisemiotic in nature and includes video and audio material as well as material containing combinations of static images and text. The majority of this material is produced in Arabic, however some is produced in other languages, with English being the most frequently used language other than Arabic (Zelin, 2015, 89). Among the material in English are the magazines Dabiq and Rumiyah. These magazines are carefully and professionally produced and are readily accessible online.

Between July 14, 2014 and July 31, 2016 ISIS released 15 issues of Dabiq magazine. Following the final issue of Dabiq, on September 6, 2016, the first issue of Rumiyah was released. Since then, up until September, 2017 a further 12 issues of Rumiyah had been released more or less monthly. While ISIS also releases video and audio propaganda material, Dabiq and Rumiyah represent the outlets through which ISIS spells out and propagates its whole agenda and are thus integral parts of ISIS's branding, marketing and recruitment strategies.

In addition, many of the images and quotes from texts which appear in Dabiq and Rumiyah are distributed widely through the internet as they are picked up and recontextualised by mainstream and social media. For example, the 15 issues of Dabiq contain 1,095 images. Of these 773 images appear on other websites, showing a total of 96,576 times the images have been indexed on other webpages as of July 5, 2017 (Tan, O’Halloran, Wignell, Chai and Lange, 2018). This number only includes URLs which 
are publicly accessible and can be found by readily available reverse image searching software such as TinEye1. Such searches do not include distribution by clandestine means. Moreover, the number of hits is also only an indicator of how ISIS materials are circulated. It does not, for example, account for the number of views received for particular images has. For instance, an image on one site could potentially be seen by millions while an image on another site might only be seen by a handful of people.

Such a large volume of data is impossible to collect and analyse manually. Thus, one of the aims of this study is to conduct a small-scale study with a view to informing much larger-scale automated and semi-automated analyses of large sets of terrorist materials and their re-use in online media. In order to achieve this, this paper adopts two strategies. First, a sample of multimodal combinations of text and image as they are presented in Dabiq and Rumiyah are analysed in order to examine patterns of contextualisation of images and text. Second, a sample of example images which reappear on other websites (e.g. Western news websites, blogs) is then analysed in order to identify patterns of similarity and difference when images and text are recontextualised in online media. The larger aim of this study is to explore how these investigations can assist in developing tools for automated and semi-automated analysis for large datasets. For this purpose, a sample of typical examples has been chosen for detailed discussion in this paper. The theoretical approach for the analyses of the text, image and their relations is discussed below. Following this, the rationale, procedure and method for achieving these aims is presented in the methodology section. Lastly, the results and conclusions are presented. 


\section{Theoretical Framework}

The theoretical approach taken in this study is referred to as Systemic Functional Multimodal Discourse Analysis (SF-MDA). SF-MDA builds upon Michael Halliday's systemic functional theory (SFT) (e.g. Halliday, 1978, 1994; Halliday and Matthiessen, 2014). Halliday's (1994, xiv) systemic theory is 'a theory of meaning as choice, by which language, or any other any other semiotic system, is interpreted as networks of interlocking options', with the particular choices that are made viewed as being made from 'a set of possible alternatives' (Halliday 1994, xiv-xxvi). SFT was initially applied to language but has since been adapted and extended for application to the study of other semiotic resources and to multimodal texts and artifacts to account for the ways in which linguistic and non-linguistic resources combine and interact in communicating meaning (e.g. Bateman, 2014; Kress and van Leeuwen, 2006; O’Halloran, 2008, O’Toole, 2011; Royce, 2007, 2015; van Leeuwen, 2005, Martinec and Salway, 2005).

One of the key tenets in SFT is Halliday's principle of metafunctions, which regards language and other semiotic systems as being structured to realise three kinds of meanings simultaneously: (a) ideational meaning, which consists of two aspects: experiential meaning for construing our experience and knowledge of the world and logical meaning, for making connections between and among events in that world; (b) interpersonal meaning for enacting social relations and expressing attitudes; and (c) textual meaning for organizing meanings into coherent messages (e.g. Halliday, 1978; Halliday and Matthiessen, 2014).

From an SF-MDA perspective, the metafunctional principle plays a crucial role in determining the functionalities and underlying the organisation of semiotic resources, and for investigating the ways in which semiotic choices combine and interact in 
multimodal texts to create meaning. This investigation is complemented by concepts from social semiotics, critical discourse analysis, photography, film theory and visual design (e.g. Kress and van Leeuwen, 2006). This does not imply that systems which have been developed for the study of language can be directly superimposed on to meanings constructed through other forms of semiosis but, rather, that the principle of metafunctions underlies the semiotic resources through which humans make meaning (see O'Toole, 2011 for an illustration of the application of the metafunctional principle to the analysis of art and architecture).

A discourse semantic perspective to image and text relations is adopted in this study. Ideas from Martin and Rose (2003) on the ideational systems of ideation and conjunction; textual systems of identification and periodicity; and interpersonal systems of appraisal are used to support a metafunctional interpretation (see Martin and Rose, 2003, 22-205 for a detailed discussion of these systems as they apply to language). These are not used for detailed analysis but rather in an exploratory manner to inform the interpretation of patterns of image and text relations.

Ideation is used to analyse what can be referred to as the 'content' of texts and images and their relations. What is going on in the text or image, 'how participants in these activities are described, how they are classified and what they are composed of. Ideation, therefore is concerned with our material and symbolic experience of 'reality' (Martin and Rose, 2003, 66). In this study connections, if any, between the content of the text and the content of the image are examined. Conjunction examines logical connections between and among events (Martin and Rose, 2003, 110). Systems of conjunction are used to explore explicit and implicit connections between text and images. 
Periodicity is used to explore how images fit into the flow of information in a text. For example, how do features such as the size and placement of images contribute to the overall meaning of a text? Martin and Rose (2003, 175-205) extend Halliday's systems of information structure (Theme and Rheme, Given and New) (Halliday, 1994, 37-67) and apply them to larger scale units of text. Identification is used to explore the relationships between participants and entities in a text and participants and identities in images in the text. For example, does an image function to identify a specific person, place or thing in a text?

Martin and Rose $(2003,22)$ define appraisal as being 'concerned with evaluation: the kinds of attitudes that are negotiated in a text, the strength of the feelings involved and the ways in which values are sourced and readers aligned.' The relevant appraisal options in this study are whether affect is positive or negative and the source of the affect. Some assessment of attitude and feelings, where they are coming from and where they are directed is essential in assessing whether a text is being used to support or oppose terrorism.

\section{Methodology}

This study is informed by previous work which uses a mixed methods approach to explore text and image relations in violent extremist discourse (see O’Halloran, Tan, Wignell and Lange, 2017 in press; Wignell, Tan, O’Halloran and Lange, 2017; O’Halloran, Tan, Wignell, Bateman, Pham, Grossman and Vande Moere, 2016, Tan, O’Halloran, Wignell, Chai and Lange, 2018). These studies identified general patterns of association between image categories and article types and temporal patterns of recontextualisation as well as the extent of recontextualisation on a large-scale. 
However, these studies do not investigate how images function in individual articles or the specific connections between images and the text in these articles. In addition, the earlier research proposes data analysis and visualisation on a larger scale than used in this paper, providing the background and context for this paper. Specifically, this paper draws on classifications of article types and images in Dabiq and Rumiyah developed by Tan et al. (2018) and O’Halloran et al. (2017 in press). This paper is also informed by work by O'Halloran, Tan \& Wignell (2016, 2017 in press) which developed an SFMDA approach for the analysis of text and image relations.

The images found in Dabiq and Rumiyah have different sources: that is, some are produced specifically for the magazines; others are found in other ISIS materials (e.g. videos, social media); others are from mainstream media, often heavily edited; and others are stock images from various image banks. Using largely experiential criteria (i.e. the content of the images), the images were classified into eight superordinate image categories (see Tan et al., 2018). For example, images containing any one of or any combination of the ISIS flag, the AK47 assault rifle and/or what we refer to as the tawheed gesture (index finger extended and pointing upwards, symbolising the indivisible one-ness of Allah), are classified as ISIS icons (see Wignell et al, 2016, 2017).

The text in the magazines is largely original to ISIS. In terms of style and tone, most of the articles found in Dabiq and Rumiyah are inspired by ISIS's narrow and rigid interpretation of Islam, which is used to promote and legitimise ISIS's values and world view (O’Halloran et al., 2017 in press; Wignell et al., 2016; Wignell, Tan and O’Halloran, 2017). 
Wignell, Tan, O'Halloran and Lange (2017) classified the articles of all issues of Dabiq and 12 issues of Rumiyah available at that time into types according to article titles and the article's content focus: largely experiential criteria but also drawing on interpersonal and textual features. There were 290 articles in Dabiq and 229 in Rumiyah. From these twenty article types were identified, ten of which are common to both magazines, six are found in Dabiq but not in Rumiyah and four are found in Rumiyah but not Dabiq (Wignell, Tan, O'Halloran and Lange 2017). The articles include religiously inspired articles setting out ISIS's interpretation of Islam, articles on what ISIS regards as the obligations of mujahideen, women and supporters, articles denouncing ISIS's 'enemies', articles glorifying the life and deeds of ISIS 'martyrs' and articles providing instructions on how to carry out lone-wolf terror attacks (see Wignell et al, 2017, 45).The classifications of the images and article types form the basis for selection of the dataset, as described below.

\section{Data set}

The initial data set for this study consisted of all the articles in Dabiq (Issues 1-15) and Rumiyah (Issues 1-12). The articles and associated images were first examined to identify patterns of contextualisation. From these one typical example of each of the article types identified by Wignell, Tan, O'Halloran and Lange (2017) was selected for further analysis. From this sample, image and text relations in a smaller sub-set of four examples were then analysed and discussed using an SF-MDA approach. These four examples were selected on the basis that these were typical article types and image types which function to promote ISIS propaganda. The four examples were chosen as many articles contained images with different functions and these examples represented 
the minimum number that would capture the three image functions found in the magazines. The image functions are discussed in Analysis and Discussion below.

A reverse image search using TinEye was then conducted on a sample of the images in this sub-set to find examples of their redistribution after publication in Dabiq or Rumiyah. Selected examples of recontextualisation of images from the initial sub-set were then analysed and discussed using the same approach as was used for the images and text in their original context. A comparison is then made between the functions of the images and text in Dabiq and Rumiyah and in their recontextualisations in online media sites.

\section{Analysis and Discussion}

In a study of the iconisation employed by ISIS in Dabiq magazine, Wignell et al (2016, 18) propose that:

'when taken collectively the various combinations of text and image build an internally cohesive world view, which constructs ISIS's vision of an idealised world built according to a re-imagining of the earlier Islamic principles and practices. This world is actively and violently opposed to an anti-world of 'near' and 'far' enemies: the world of $k u f r$ : a world populated by apostate Muslims, idol-worshippers, Crusaders and Jews.'

This vision of the world-as-it-should-be according to ISIS is presented and built through complex intersemiotic relations among texts and images, condensed in visual form into 'bonding icons' (See Martin and Stenglin, 2007) that synthesise and reinforce the world view and values put forward by ISIS. This world view and values provide the background for ISIS propaganda material. While the earlier study focussed on the use and role of bonding icons in constructing ISIS's world view and its supporting values 
(Wignell et al., 2016), the current study examines the functions of the text and image relations more globally.

Based on metafunctional criteria, the larger scale exploration of the functions of images in relation to their accompanying text revealed three broad functions of images: images which have what we refer to as a 'documentary function'; images which function as 'symbols'; and images which contain features of both of the other two groups, referred to as having a 'symbolic/documentary' function. Examples of articles illustrating each of these image functions are analysed and discussed below. Image functions associated with article types are then summarised in Figure 5, which shows typical patterns of association among article types and the function of images in each example. This is followed by a discussion of examples of some typical patterns of contextualisation.

\section{Documentary images}

Images with the 'documentary' function depict or refer to specific (or generic) people, actions, places or things. These images are typically captioned and can be related directly to specific parts of their accompanying text. Documentary images come in two types: those shot in situ at or close to the time and location as the events reported on in the article; and those which function as a generic example of a class of objects or people and which are not tied to any particular time or place. Figure $1 \mathrm{a}$ and $1 \mathrm{~b}$, illustrate the first type of documentary image function and Figure 2 illustrates the second type. 
THE FIGHT FOR WILĀYAT AL-ANBĀR

\section{THE FIGHT FOR WILĀYAT AL-ANBĀR}

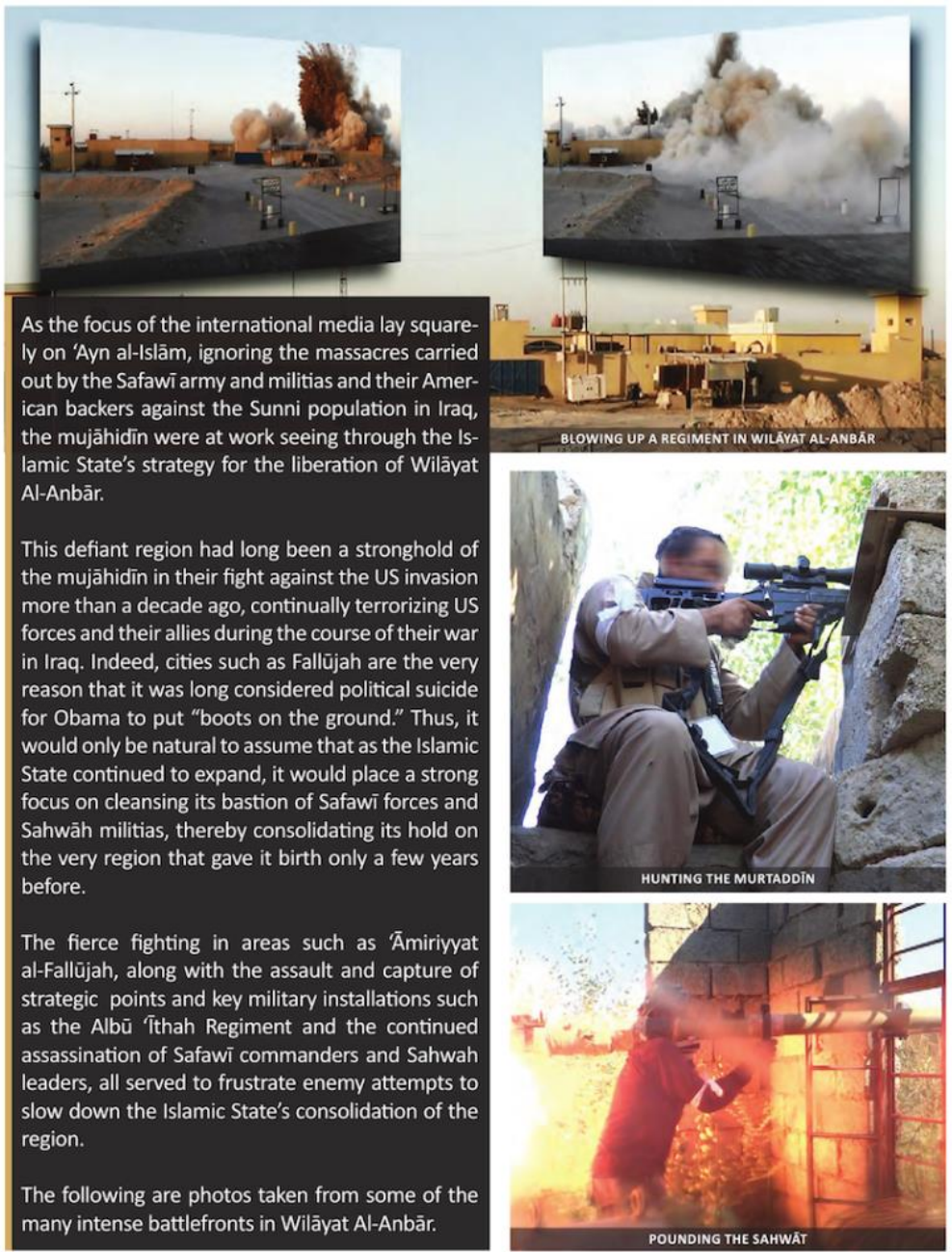

10 REPORT

\section{Figure 1a}

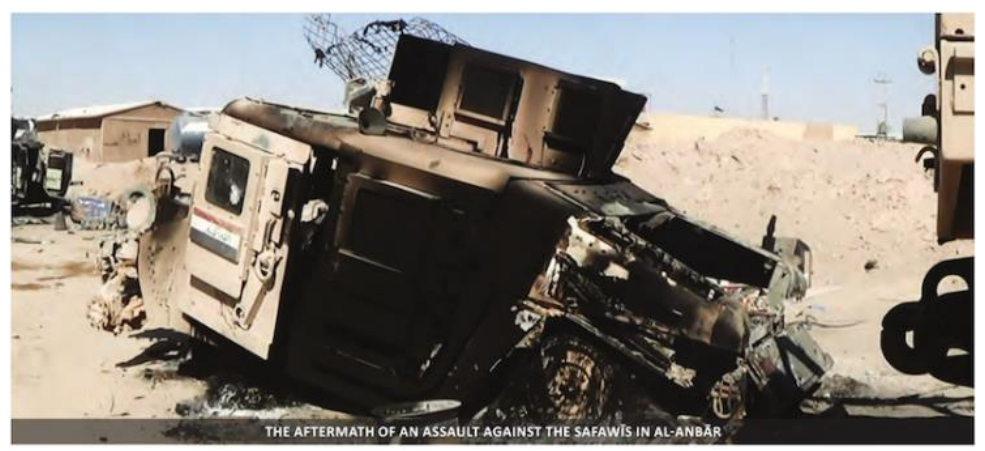

Figure 1b

Figure 1: Documentary images in a report of ISIS military operations (Dabiq, Issue 5, 10-11) 
The images in Figure 1a and $1 \mathrm{~b}$ are from an article which reports on ISIS military operations. Articles of this type are found in almost every issue of Dabiq and Rumiyah. The images depict events and locations in the battle. The captions under the images refer to participants, events and places in the text. For example, Sahwat in the caption under the lower right image adjacent to the text (Figure 1a), and mentioned in the second paragraph of the text, refers to a group of anti-ISIS Arab forces. Safawi in the caption in the image at the bottom, and in the first two paragraphs, refers to Shi'a Muslim forces (inferring association with Iran), while murtaddin (apostates) in the middle image refers to both Sahwat and Safawi forces, both considered murtaddin by ISIS. The top three images in Figure 1a show military action and identify its specific location, Wilayat al-Anbar (al-Anbar Province). Experientially the images visually identify places and events reported on in the text. In this sense they serve as a kind of visual verification that the events reported on in the text actually happened.

The Arabic vocabulary in the text draws from ISIS's taxonomy of its enemies (Safawi, Sahwat, murtaddin), identifying them and locating them in a wider context in opposition to ISIS forces (mujahideen). Interpersonally this taxonomy of enemies has a strong negative loading. In terms of logical meaning, the images tend to have a relationship of explicit similarity (see Martin and Rose, 2003, 115) with specific parts of the accompanying text in that they exemplify visually parts of the text.

Textually the images from the first page of the article are prominent, as they occupy close to two thirds of the page and frame the text on two sides. They are not, however, thematic in that they are positioned relatively close to the parts of the text to which they refer and do not have a larger scale role in organising the flow of information in the 
article. Their role is more one providing visual identification for specific parts of the text. Figure $1 \mathrm{~b}$ is the last of a vertical sequence of images which make up the second (and final) page of the article. The three images sharing the same caption under the headline identify the location as Wilayat al-Anbar, while the other images are adjacent to parts of the text which refer to ISIS's enemies.

The images, and captions, also have an interpersonal function in that they depict ISIS in 'righteous' action and achieving victory over their enemies, which is likely to resonate with their supporters. In terms of affect, ISIS forces are cast in a highly positive light while those opposing ISIS are portrayed highly negatively, with Arabic terms used to express strong negativity. In this article, the interpersonal is least foregrounded, followed by the textual, with the ideational metafunction most prominent. That is, the text is largely concerned with happenings (participants, process and circumstances) and logical connections between those events.
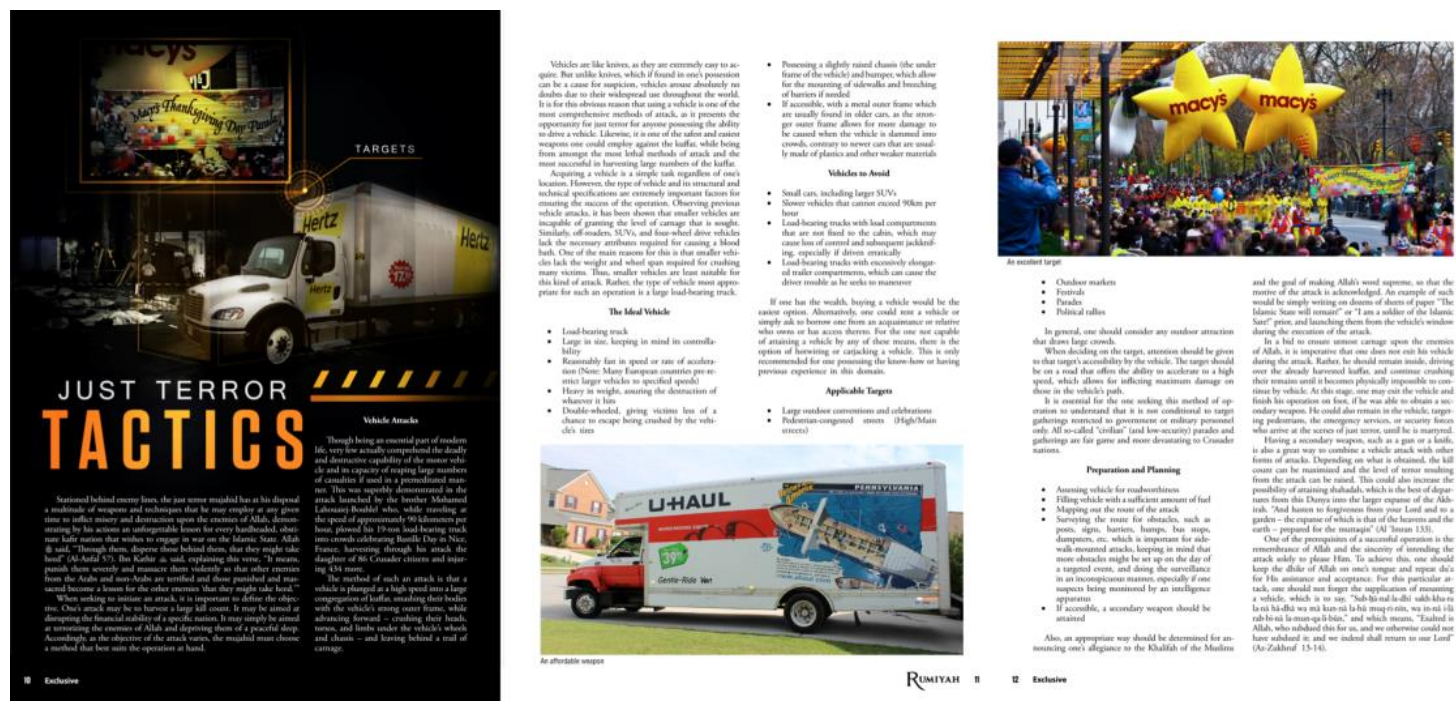

Figure 2: Documentary and symbolic/documentary images in a procedural article (Rumiyah, Issue 3, 10-12) 
Figure 2 illustrates the second use of images with a documentary function and introduces symbolic/documentary images. The article shown in Figure 2 is an example of a type of article classified as 'Procedural'. These articles did not appear in Dabiq and first appeared in Issue 2 of Rumiyah. Procedural articles provide explicit instructions on how to plan and conduct 'lone-wolf' terror attacks. For example, the article shown in Figure 2, from Issue 3 of Rumiyah (released on November 11, 2016) has provided the blueprint for a string of subsequent vehicular attacks such as the Berlin Christmas market attack in December, 2016; the Westminster Bridge attack in London in March, 2017; the London Bridge attack in June, 2017; the Barcelona attack in August, 2017; and the New York attack on October 31, 2017. The attack in Nice on Bastille Day, 2016, preceded the publication of Issue 3 of Rumiyah by several months and might be seen as a prototype which, when shown to be effective, was used as a model for further attacks. This attack is described as a model for vehicular attacks in the introduction of the article.

The images in this article function differently. The two images embedded in the text of the article show generic examples of a potential 'weapon' and a potential location for an attack. The image of the van, which has the caption 'an affordable weapon', is situated immediately below a description of a suitable vehicle to use in an attack in the text. The second image, captioned 'An excellent target' is positioned in the middle of a list of the features of suitable 'targets'. These are examples of possible (rather than actual) 'weapons' and 'targets' and position any attacks instigated by the article in the future. Experientially they identify generic types (rather than specific instances) but the image of the truck and the location match the descriptions provided in the text. Logically the 
images relate to the accompanying text in the same way as images and text relate in Figure $1 \mathrm{a}$ and $\mathrm{b}$. They connect explicitly through relations of similarity.

Textually the two images are in close proximity to the text to which they connect. They are not, however, positioned explicitly in positions of textual prominence of either foregrounding what is to come or presenting something which is summative or new information (i.e. Martin and Rose, 2003, 175-205). The referential connection between, say, the image of the truck and the description of a suitable truck is generic: the description is not of that truck but any truck with the attributes described in the text. The role of these two images in the article is largely ideational, providing images to guide the selection of a 'suitable' truck and location.

This contrasts with the function of the image which occupies the first page of the article (see the image on the left in Figure 2), which is an example of the combined documentary and symbolic functions of images. The image occupies the top half of the page. The bottom half of the page displays the main text in white against a black background. The two halves of the page are separated by the headline 'JUST TERROR TACTICS' ('Just' refers to 'just' as in 'justice', implying that ISIS's tactics are justified). Also serving to separate the two halves of the page is the underlined line of diagonal black and gold bars, mimicking the pattern of some types of crime scene tape.

This separation foregrounds the textual metafunction. The image is situated above the headline and the text of the article, which positions it as a major or Macro theme, functioning on a higher organising scale as a theme for the whole article (see Martin and Rose, 2003, 175-205 for a discussion of scales of thematic organisation). As a Macro theme it has a predictive function in relation to the unfolding of the text, as elements of the image are later picked up in the article. The relations between the image of the truck 
and the Macy's parade on the subsequent pages are developed in the article in words and images. The image of casualties lying on a footpath relates inferentially to the headline, to the description of the Nice attack in the introduction, under the crime scene patterned bar, and to the message of the article.

Along with the textual metafunction, there is also a strong interpersonal component. The dark background and the stark and dark lighting of the images draws the viewer's attention, as does the contrasting orange and large type of the word 'TACTICS' in the headline. This also connects back to the images above as the truck and the parade are both examples of tactics. The language of the article's text is also strongly positive towards ISIS and its supporters and negative towards everyone else.

\section{Symbolic images}

The two images in Figure 3 are examples of images with a symbolic function. The article is an example of a type that ISIS refer to as Hikmah (Wisdom). The text of these articles is religiously inspired and uses citations from Islamic scripture extensively to steer 'believers' down the 'correct' path. The images, however, have no explicit connection to the text. 


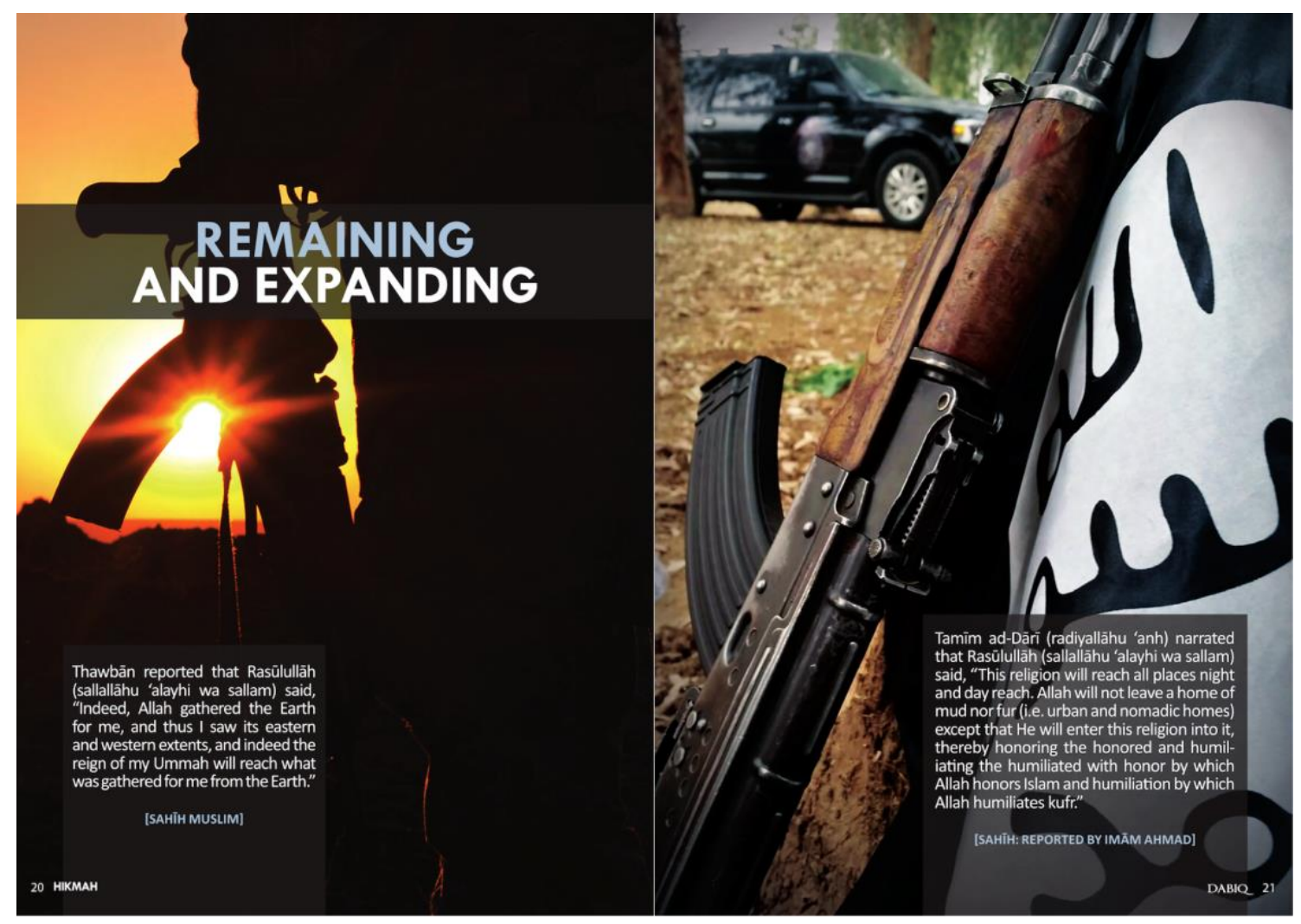

Figure 3: Symbolic images from a religiously inspired article (Dabiq Issue 5, 20-21)

The article's headline repeats the title of this issue of Dabiq and also foreshadows the following feature article, which also carries the same headline. The text of the article consists of two citations from Islamic scripture. The citations are used as 'proof' that ISIS's 'brand' of Islam will both remain and expand. The text is superimposed over two images that feature combinations of ISIS icons (see Wignell et al, 2016). The image on the left in Figure 3 shows the silhouette of an AK47 assault rifle and the partial silhouette of a mujahid facing either the sunrise or sunset. The image on the right features an AK47 assault rifle aligned diagonally next to the ISIS flag. There is no mention of mujahideen, AK47s or ISIS flags in the text of the article. The icons in the images symbolise jihad (Wignell et al., 2016) and in combination with the scripture they symbolise both the righteousness and the means of 'remaining and expanding'. While the images are photographs of objects, they are not captioned or located in 
relation to any events. Their symbolic function highlights their interpersonal associations as ISIS icons.

Textually the positioning of the images has them functioning as Macro theme and a Macro new respectively for the article, thus foregrounding textually these interpersonal associations. The affect is also positive towards ISIS and negative to everyone else but here it tends to be expressed through selected citations from Islamic scripture, which are linked to the ISIS icons by being superimposed over them.

\section{Symbolic/documentary images}

The article shown in Figure 4 is an example of an article type referred to as 'Among the Believers are Men'. The title is a contraction of a citation from the Qur'an:

'Among the believers are men true to what they promised Allah. Among them is he who has fulfilled his vow [to the death], and among them is he who awaits [his chance]. And they did not alter [the terms of their commitment] by any alteration' (Surah Al-Azhab $33: 23)$.

The verse is about martyrdom and the steadfastness of martyrs. Articles in this category present a kind of biographical narrative of highlights of the life and deeds of a 'martyr', emphasising his religious devotion and his devotion to his ISIS 'brothers'. The lead image occupies most of the first page of the article, with the introductory paragraphs positioned in the bottom left hand corner. In the top left hand corner are the headline and the nom de guerre of the 'martyr', Abu Qudamah Al-Misri. The image and the headline function textually as Macro theme for the article. The text on this page begins the part of the 'martyr's' life story that is relevant to the article: leaving London (and his baby daughter) behind to migrate to ISIS territory. 

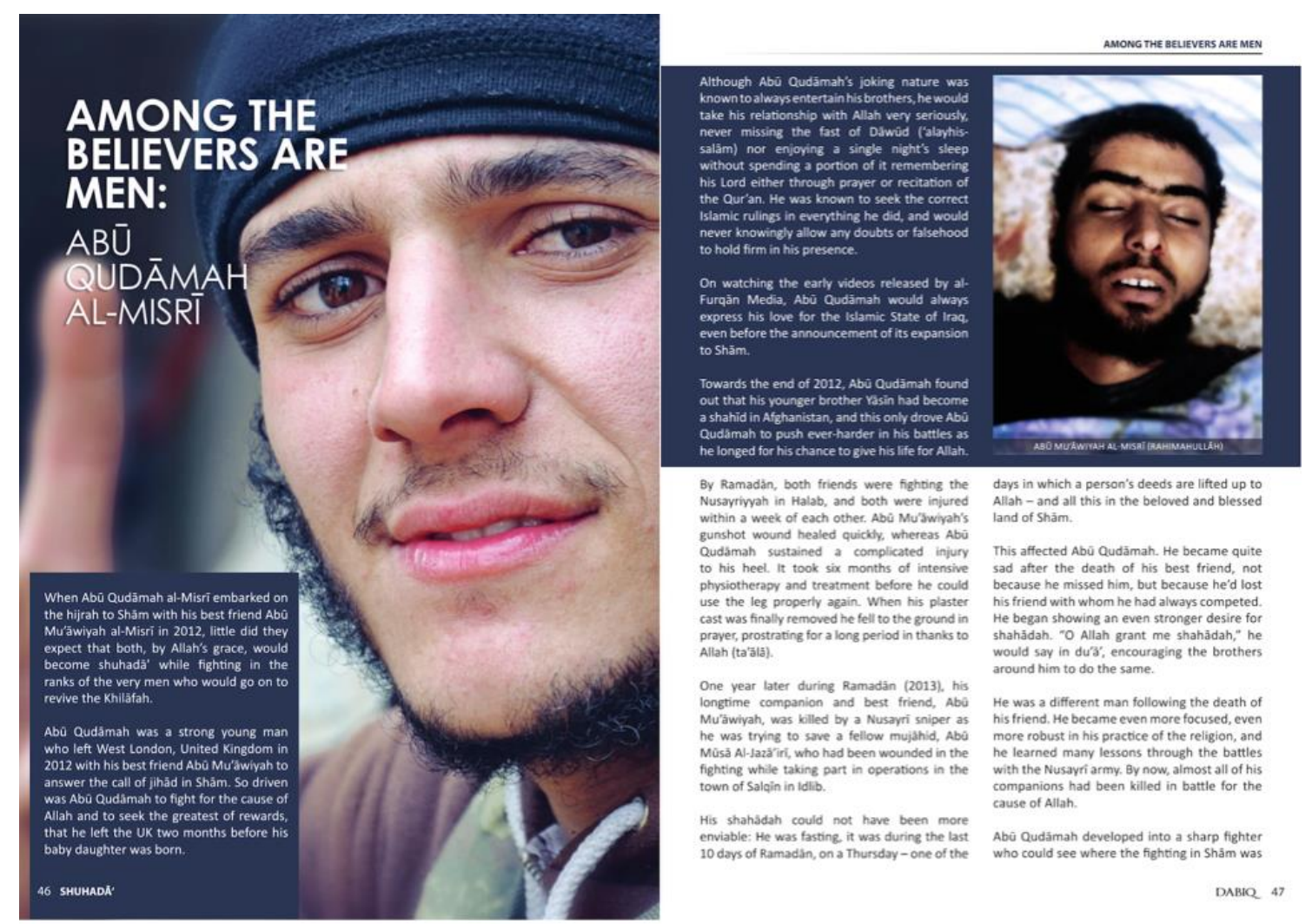

By Ramadidn, both friends were fighting the

days in which a person's deeds are lifted up to
allah wand all his in the beloved and blessed Nussyriwyah in Halab, and both were injured gunshot wound healed quichly, whereas Abi Qudasmah sustained a compicated injury
to his heel. it took six months of intensive physiotherapy and treatment before he could use the leg property again. When his plaster cast was finally removed he fell to the ground in

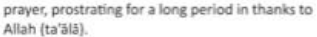

One year later during Ramadàn (2013), his longrime companion and best friend, Abu he was tring to sove a fellow mujajhid, Abi

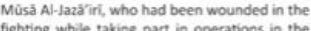
fighting while taking a par

His shahadah could not have been more
enviable: He was fasting it was during the last and of Shàm.

This affected Abu Qudàmah. He became quite sad atter the death of his best triend, not his friend with whom he had always competed.
He began showing an even stronger desire for hahahadah. "O Allah grant me shahä̉ah," he would say

He was a different man following the death of instriend. He became even more focuseded, even he leobsest his practice of the religion, and

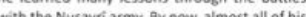
companions had been killed in batte tor the of Allat

Abũ Qudasmah developed into a sharp fighter
who could see where the fighting in Shàm was

DABв 47

AMONG Tre BeLUVERS ARE MER

headed. He had originally entered the country inrough the tem iry or the free Syrian Army. grew. In 2013, he would say to other brothers, "Watch the FSA, because those people are going to fight us soon." Thus, he was known

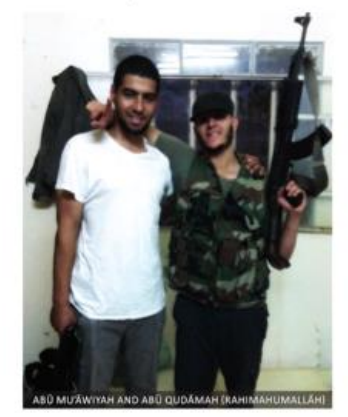

It wasn't long after his recovery that he joined the battle for the viliage of Duwayrinah near Halab, spending around ten days in ribat. He would distribute food to the brothers at the area was very dangerous and, as such, the cood had someth qualities were noticed in him and he was given rontline, coordinating their ribat hours and

During an advance by the Nusayri army in which many brothers were killed and injured for its close proximity to the enemy and the heary weapon

48 SHUHADQ̄ं
"Paradise is under the shades of swordst" over under fire.

On the tenth day of ribat, he and his companions entered Duwayrinah to relieve group of mujachidin, reptacing them with a call for help it was a medic out of breath, aying that there was a fallen brother at a ribst point called "al-Qalb" - the heart.

They all rushed to see what was happening. When ther reachod me location, they found ouse that was facing enemy positions and known to be covered by an enemy sniper. The wounded brother was very exposed and there was no cover apart from a thin curtain hangir

Where is he hit?" asked Abũ Qudảmah. "In the stomach, shot 5 times," said one of the brothers who witnessed the shooting. The his shahadahah over and over again.

the sniper was not shooting, so the mujahidi new it was an old technique to draw in edic and get more kills. Abü Qudarmah didn't

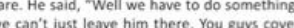
twe can't just leave him thy

After a short discussion, the group agreed and the plan was set. While the medic ran over grab the wounded brother, the rest of the of the sniper.

"We don't want two brothers out there instead " onel" one of the brothers warned the medic rescue mission was launched. Wwas a difficult situation but no one had a better The dand the injured brothers

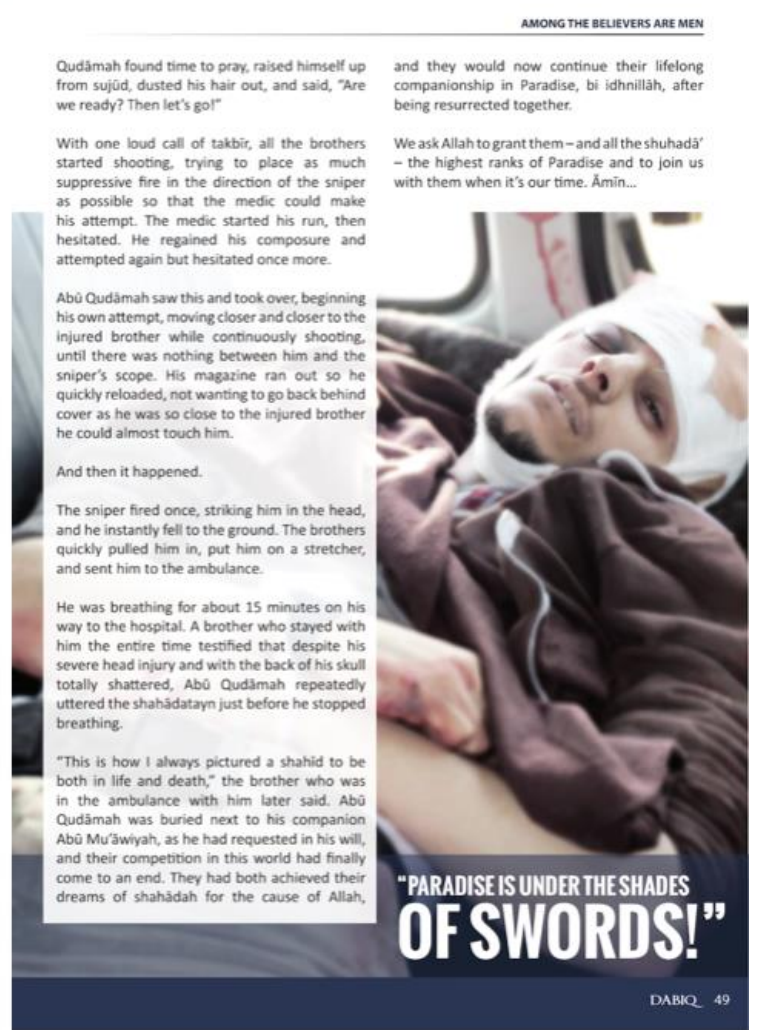

Figure 4: Symbolic/documentary images from article Among the Believers are Men (Dabiq, Issue 7, 46-49) 
The image is documentary in the sense that it is a photograph of an identified individual who is also the main character in the biographical narrative. It is symbolic in the sense that, as well as being an individual, he is presented as a model mujahid, who has achieved his wish to become a 'martyr', thus becoming a role model for all mujahideen. This individual thus has iconic status as an ISIS 'hero'. The close up, portrait shot and the subject's direct gaze at the viewer create an effect of interpersonal closeness. This is reinforced by the iconic gesture of the raised index finger, which supports the subject's iconic status. These features have a strong interpersonal loading.

The images on the second and third pages of the article have a more documentary function. The image on the second page, showing Abu Qudamah's companion, Abu Mu'awiyah Al-Misri, in death has an ideational function, showing visual 'proof' of death, however, since the deceased is a 'martyr' (an ISIS hero) it also has an interpersonal function. The captioned image on the third page of the article has a documentary function, showing both 'martyrs' as brothers in arms. The final image, showing the mortally wounded Abu Qudamah, functions textually as a kind of visual Macro new and has both a documentary and a symbolic function. The interpersonal aspect is highlighted by the scriptural citation 'Paradise is under the shade of swords!' (Sahih Bukhari, Vol 4, Book 52, Number 73) in large type and in capital letters. Affect is largely carried through the positive reporting of the deeds of the 'martyrs' and their religious devotion.

\section{Summary: Typical Associations between Article Types and Image Functions in Dabiq and Rumiyah}

The most typical associations between article types, the three image functions and metafunctions are shown in Figure 5. These are not intended to be categorical, however they are intended to display tendencies. While the text and images in each article 
involve choices from each metafunction, some patterns of image functions in relation to articles seem evident. For example, symbolic images and symbolic/documentary images, which have a strong interpersonal loading through the use of ISIS icons, tend to also be found at points of textual prominence in articles, functioning either as visual Macro themes or Macro news. The difference between these two image functions appears to be in the article types they are most commonly associated with. For example, articles which are strongly religious in focus such as Hikmah and many feature articles tend to feature symbolic images which feature ISIS icons which are not explicitly referred to in the articles. Images with a symbolic/documentary function are still highly interpersonally charged but are less abstract, since they are typically images of identifiable people or objects referred to explicitly in their articles but which also function as examples of ISIS virtues and values. On the other hand, documentary images tend to have a closer proximity to the events and people they refer to in the text, foregrounding ideational meaning. All of the articles feature strong positive affect for ISIS, with the source of this affect being ISIS themselves and their own narrow and selective interpretation of Islamic scripture. In contrast, all of the articles feature strong negative affect from ISIS towards ISIS's 'enemies', with the source of the negativity also being ISIS, supported by their own interpretations of scripture. Many of the terms carrying both the positive and negative affect are Arabic and are drawn from a relatively small set Arabic words used throughout all issues of Dabiq and Rumiyah to denigrate their 'enemies'. 


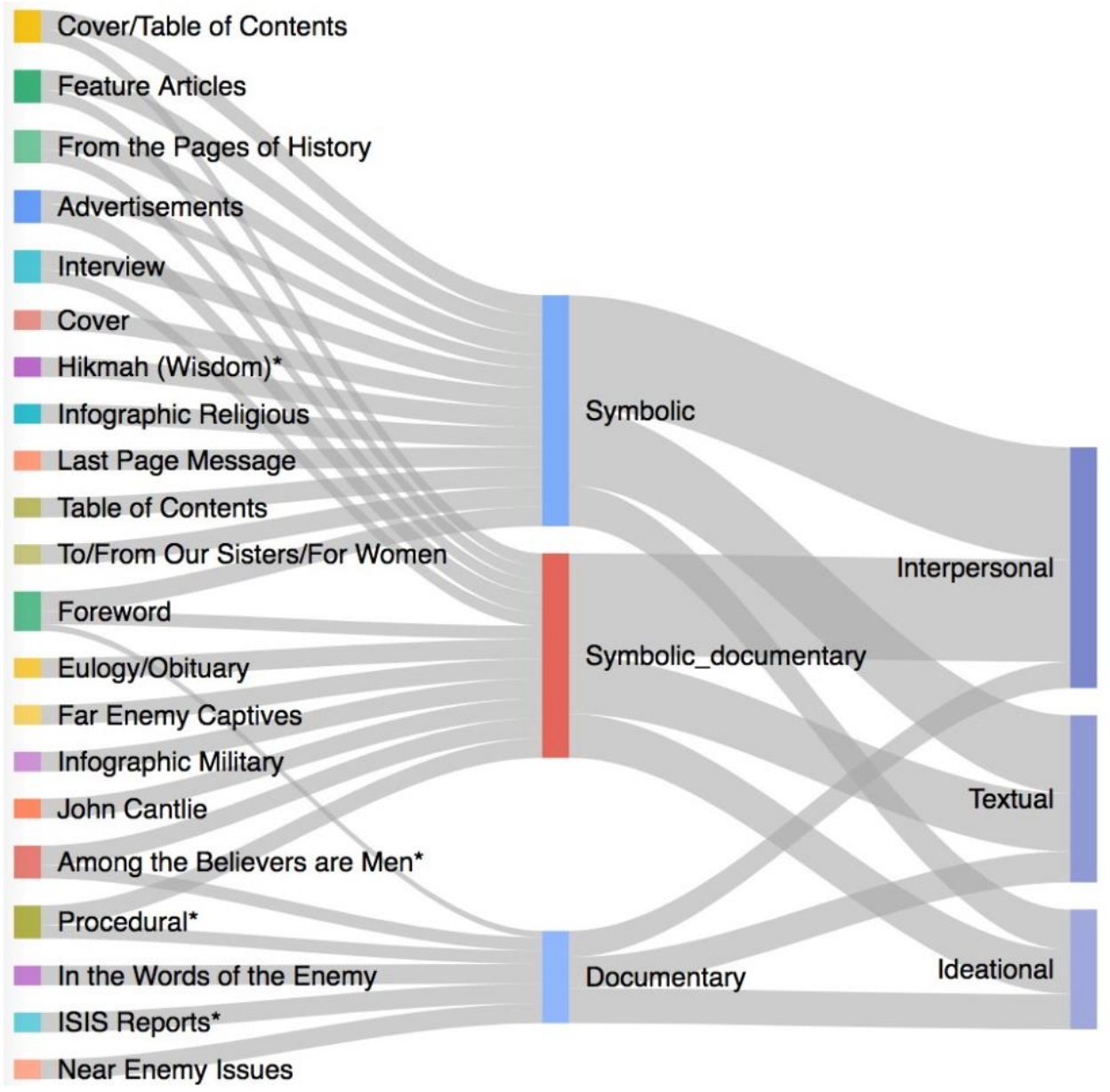

Figure 5: Typical Associations between Article Types and Image Functions in a sample of one of each article type in Dabiq and Rumiyah

\section{A sample of recontextualised images}

Examples from the sample of images discussed in their context in Dabiq and Rumiyah are now explored in terms of their recontextualisation in online media. All of the images in Dabiq and Rumiyah can be assumed to support and promote terrorism while the images, when recontextualised in the examples examined here, are situated in articles which, report on and, implicitly or explicitly, oppose terrorism. The examples have been taken from a variety of different types of websites. Example 1 is from the Foundation for Defense of Democracies' FDD Long War Journal, an American non-profit news 
site which reports on the war on terror. Example 2 is taken from a personal blog, tomfernandez28's blog'3. Example 3 is from the Australian edition of the online newspaper, Business Insider 4 and Example 4 is from the British tabloid newspaper the Daily Mail5.

The recontextualised images are discussed first in relation to their function, in metafunctional terms, in their new context. The results are then compared and contrasted with the role of text and images in their original context in Dabiq and Rumiyah.

\section{Recontextualised documentary image}

The image displayed in Figure 6 (bottom) is the same image as the one found in Dabiq but its source is cited as having been 'disseminated on Twitter by the jihadist group's supporters after being posted elsewhere online'. The image was published in Dabiq Issue 5 on July 5, 2014 and appeared in the Long War Journal article on October, 14, 2014. In the Long War Journal article the image is found at the bottom of the article as the fourth image down in a vertical string of 19 images following a report on the same military operations in 2014 described in the ISIS report in Dabiq Issue 5 (see Figure 1).

The image in the blog post shown in Figure 6 does not have any textual prominence and is separated by quite a distance from the indirect reference to it as one of 'their snipers' in the text of the article, while in the Dabiq article the image is positioned adjacent to text which is connected lexically to it and the caption under the image says 'HUNTING THE MURTADDIN'. Although the same actions are described, the language of this report is very different from that found in Dabiq (see Figure 1). For example people classified pejoratively as murtaddin, Safawi and Sahwat in the Dabiq article are 
classified more neutrally as 'Iraqi military and their tribal allies' and 'Iranian-backed Shia militias'. ISIS is also described relatively neutrally as 'Islamic State' and 'jihadist forces'.

The images in this article are documentary in function and have a similar, largely ideational, role to the images in the corresponding Dabiq article: providing visual examples of the action being described in the text. Two differences in function are, first, the images are not located in close proximity to the text of the article, giving them reduced textual prominence, and the affect in this article is not as marked as the affect in the Dabiq article.

\section{Recontextualised symbolic image}

The article and images shown in Figure 7 come from a personal blog called 'tomfernandez28's blog'. The image is a cropped version of the bottom image displayed in Figure 3. It has been cropped so that it foregrounds two ISIS icons, the ISIS flag and the AK 47 assault rifle even more than in the original image in Dabiq. It is also positioned prominently at the beginning of the article under the headline, which reads 'GERMAN POLICE CHIEF: ISIS HIDING AMONG REFUGEES ENTERING EUROPE'. The image is captioned in orange type 'German special forces arrest two following raid on Islamic cultural center'. 


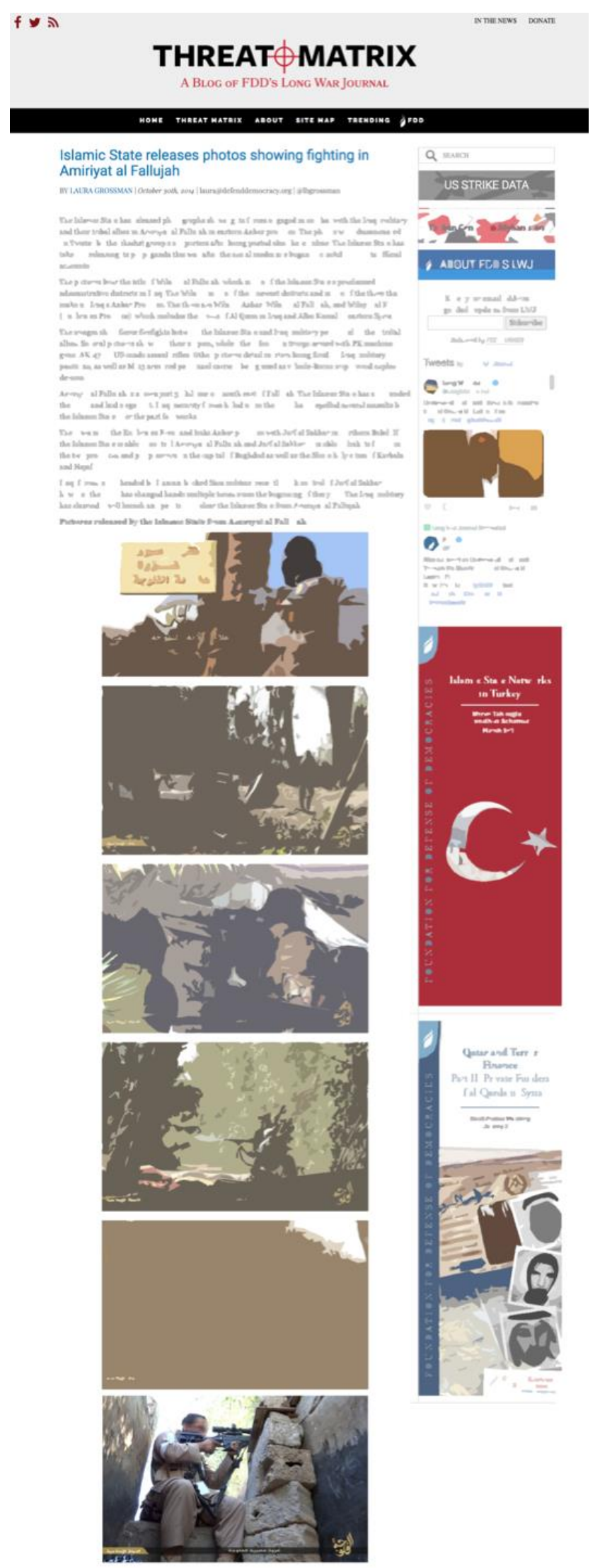

The next 15 images have been omitted

Figure 6: Recontextualised documentary image from:

https://www.longwarjournal.org/archives/2014/10/islamic_state_releases_picture_2.php 


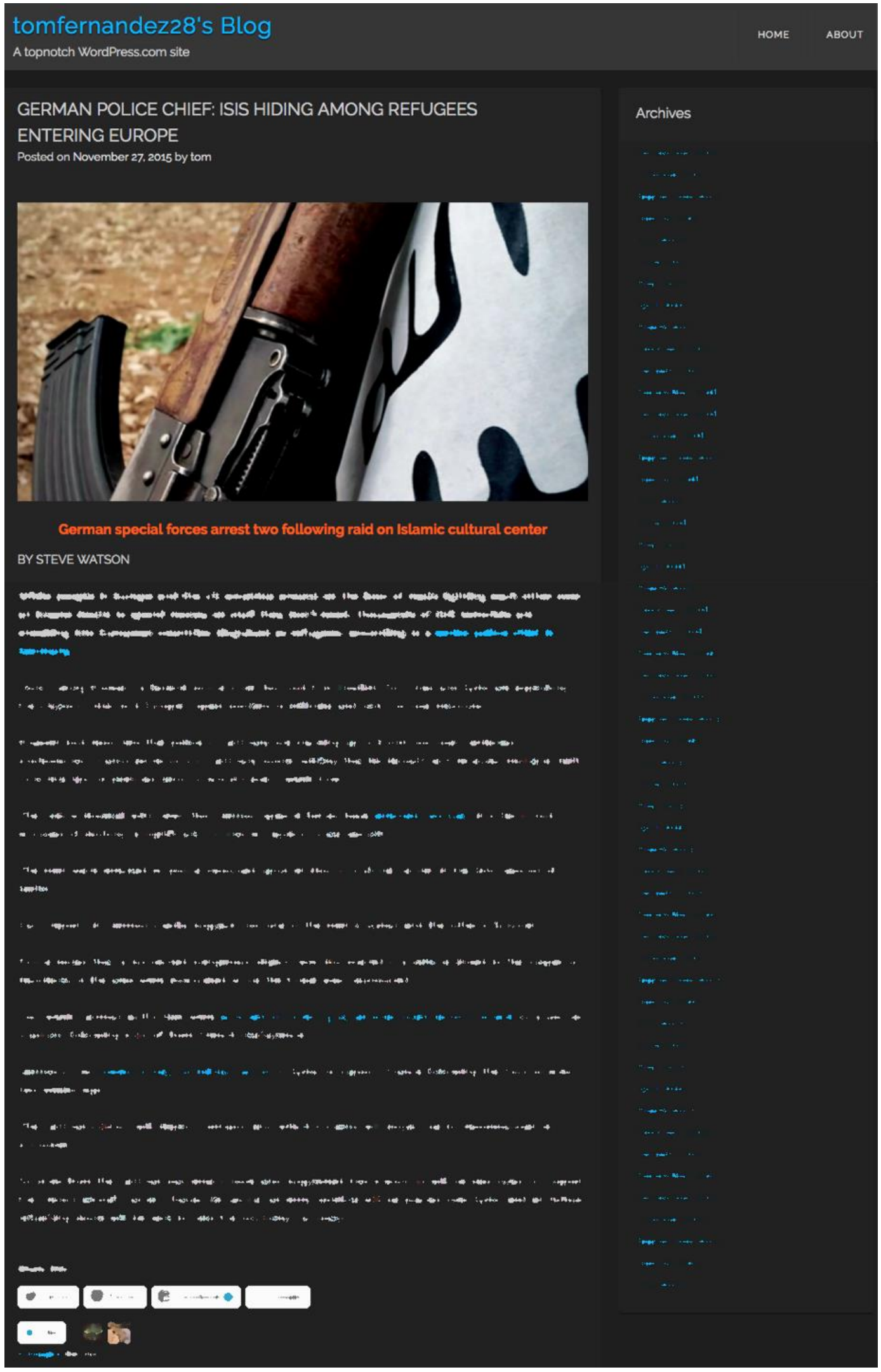

Figure 7: Recontextualised symbolic image from

https://tomfernandez28.com/2015/11/27/german-police-chief-isis-hiding-amongrefugees-entering-europe/ 
The rest of the article is a news report about the alleged infiltration of 'ISIS terrorists' into Europe posing as refugees. The image is large and textually prominent. Its ideational content, however, is not connected directly to the events recounted in the article. Ideationally the only connection with the article is the flag in the image, which uniquely identifies ISIS. As in the image's original context in Dabiq, the image here also functions symbolically and interpersonally, by showing two key ISIS icons, it draws the viewer's attention to the article by highlighting that the article is about ISIS.

\section{Recontextualised symbolic/documentary image}

The example shown in Figure 8 is taken from the online business news service,

Business Insider Australia. The article describes a terror attack at Ohio State University which used the template produced by ISIS, as is found in the article that appeared in Rumiyah Issue 3 (see Figure 2). The Business Insider article uses the symbolic/documentary image which functions as a Macro theme for the Rumiyah article. In this case only the images on the top half of the page and the words 'JUST TERROR' from the headline of the Rumiyah article have been included. The image is large and prominent but not thematic in its positioning in the text. It does, however, function textually, interpersonally and ideationally. 


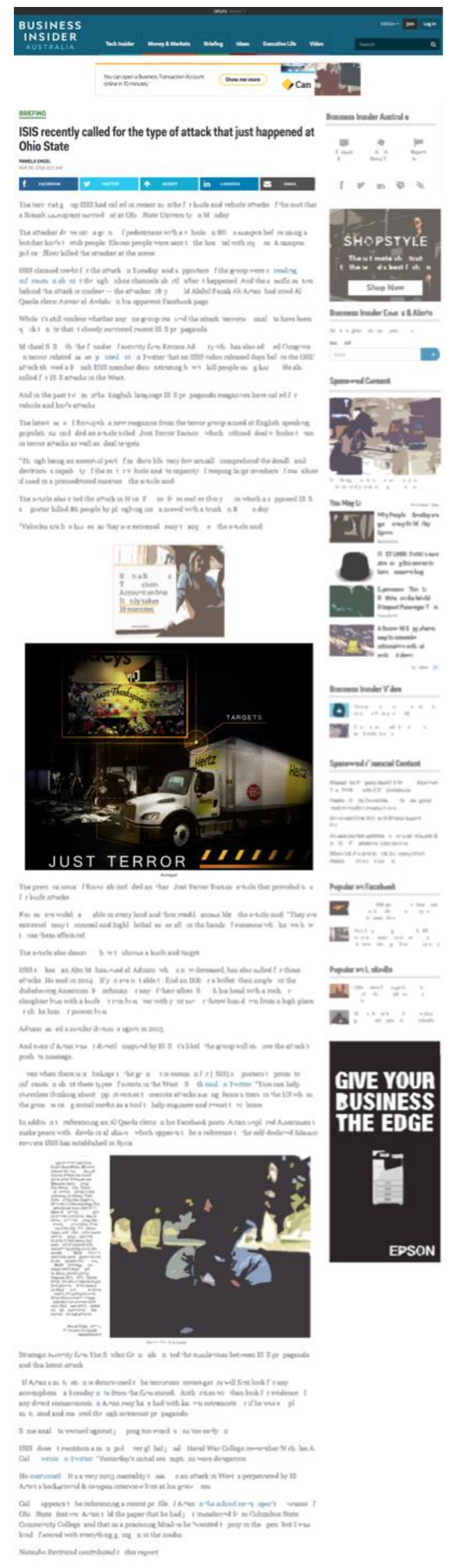

Figure 8: Recontextualised symbolic/documentary image from

https://www.businessinsider.com.au/isis-calls-for-vehicle-knife-attacks-201611 ? utm_content $=$ allverticals\&utm_medium $=$ referral\&utm_source=hearst\&r $=U S \& I R=T$ 
Interpersonally the image is eye-catching for the same reasons that it was eye-catching in Rumiyah, however, the cropping introduces a textual change, which in turn changes the interpersonal interpretation. The cropped image includes 'JUST TERROR' but excludes the word 'TACTICS', in bright orange in the original, which changes the New information focus from 'tactics' to 'terror' and eliminates ISIS's view that the terror is justified, which opens space for an anti-ISIS interpretation. This is reinforced in the text of the article. The first sentence of the text of the article describes ISIS as a 'terrorist group' and there are several references to 'terror attacks' throughout the article.

Ideationally the text of the article relates directly to a terror attack inspired by ISIS propaganda and which followed methods employing knives and vehicles proposed by ISIS in Issues two and three of Rumiyah, including direct quotes. The article also cites other ISIS sources. The image supports these by showing graphically the means ISIS recommends.

\section{Recontextualised symbolic/documentary and documentary images}

The text and images in the example shown in Figure 9 involve recontextualisations from images which first appeared in Dabiq Issue 7 (see Figure 4). The example is taken from a long article in the online version of the British tabloid newspaper the Daily Mail. The article focuses on British mujahideen who have either been killed or are suspected of having been killed while fighting for ISIS in Iraq and Syria. The main protagonists in the article are members of a group of British jihadists known as 'The Beatles' and their associates. The article explores their backgrounds, their activities while fighting for ISIS and speculates about how they were recruited. The images recontextualised from the Dabiq article appear towards the bottom of the article, almost as an afterthought. The men shown in the images are named in captions but are not referred to in the body of 
the article. While in their original context in Dabiq, one image is documentary and the other is symbolic/documentary, in the Daily Mail article they both function as documentary images. Figure 9 displays only the first part of the article and the parts showing the two recontextualised images.

\section{Summary, conclusions and possible future directions}

These preliminary results show promise for identifying directions for further exploration in a larger scale study. The differences in the relative prominence of the metafunctions, both in Dabiq and Rumiyah as shown in Figure 5 and between these and the recontextualisations is one point of interest. In Dabiq and Rumiyah, the majority of the article types appear to use symbolic and symbolic/documentary images to foreground the textual and interpersonal metafunctions. That is, these images are often large and positioned at points of textual prominence, such as at the beginnings and ends of articles. As well as being textually prominent these images also carry a strong interpersonal loading, usually featuring images of ISIS icons such as the ISIS flag, ISIS 'heroes' and the AK47 assault rifle. In the case of images which are purely symbolic the content of the image often has no explicit ideational connection to the ideational content of the article. The connection is usually implicit, connecting ISIS icons, which symbolise ISIS values, to selected references to and citations of Islamic scripture, attempting to justify ISIS righteousness as working in the name of Islam. Images functioning as symbolic/documentary have a similar function but often focus on ISIS 'heroes' as representatives of ISIS's world view and values. On the other hand, documentary images have a more ideational orientation, are more tied to events and participants, are less textually prominent and are not as highly interpersonally charged. 


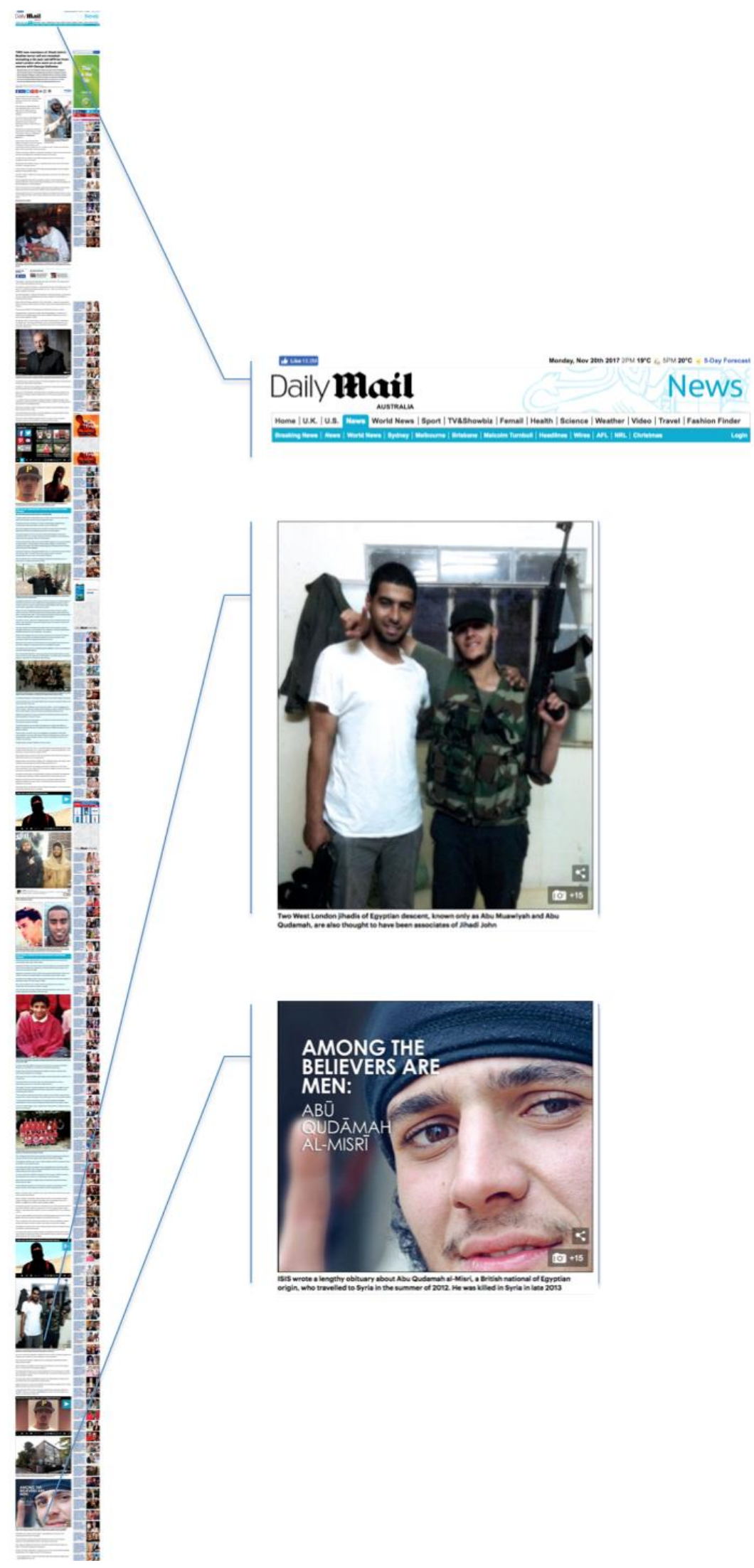

Figure 9: Recontextualised symbolic/documentary and documentary images from http://www.dailymail.co.uk/news/article-3435947/Second-member-ISIS-Beatles-QPRfan-west-London-Alexanda-Kotey-32-identified-spies-group-four.html 
The examples of recontextualised images suggest both differences and similarities which warrant further exploration. The principal trend, which can only be hypothesised but is worth further exploration, is that the images, when recontextualised tend to be used with a more documentary function. For example, images such as the lead image in Figure 4 above, are used in Dabiq as symbolic/documentary images. Such images are textually prominent and interpersonally charged and used to lead into an article about the 'heroic' deeds of a 'martyr'. However, in its recontextualisation by the Daily Mail (Figure 9) its function is documentary, used to identify a minor participant in the article. The interpersonal and textual components are diminished and the ideational function is enhanced.

There are, however, two examples in the recontextualisations where a symbolic and a symbolic-documentary image function similarly to how they function in Dabiq and Rumiyah, but with the opposite intention. The recontextualised images in Figures 7 and 8 have both been altered. The image in Figure 7 has been cropped to remove the background and only shows the two ISIS icons in close-up. This attracts the viewer's attention and makes it clear that the article is about ISIS. The same icons are used but as negatives rather than as positives, as they are used by ISIS. Similarly the top image in Figure 8, which was originally used in Rumiyah to justify and support ISIS has been cropped and used as an anti-ISIS symbol. This raises an issue regarding the duality of icons. If the same, or substantially the same, images can be used to both support and oppose terrorism, it is possible to inadvertently publicise terrorist organisations when the intention is oppose them. The principal difference is in the surrounding text but it is the interpersonally charged image which first attracts attention. 
Another point which is worth further exploration is the differences in how negative and positive affect are used in the source articles and in the recontextualisations. Dabiq and Rumiyah use quite a small set of Arabic words as their main means of expressing negative affect towards others. These include names of specific 'enemies' near and far and general terms for people ISIS feel compelled to eradicate. For example 'near' enemies include Nusaryi (Alawite Muslims - Syrian government), Rafidah (Shi'a Muslims), Sahwah (Sunni groups fighting against ISIS) and Safawi (Shi'a Muslim forces fighting against ISIS, associated with Iran). The most commonly used word applied to the 'far' enemy is crusaders. Other Arabic words used to express disapproval generally have a religious flavour and include murtadd/murtaddin (apostate(s) who have abandoned Islam), mushrikin (idol worhippers/polytheists) kufr (nonbelievers/infidels) and taghut (a secular ruler ruling by man-made law). Alternatively, positive affect towards ISIS's own is also often realised in Arabic through words such as mujahid(een) (jihadist fighter(s)), shahid (martyr), istishhad (martyrdom - often applied in the context of suicide bombers), jihad (struggle/war in defence of Islam), muhajir (person migrating to ISIS-controlled lands).

In contrast, the article containing the recontextualised images do not use Arabic terms. Negative affect towards ISIS is most commonly realised through words such as terrorist group, terror group, terrorist(s) and terror. The most neutral words used were terms such as ISIS forces and jihadi fighter(s). No words were found which showed positive affect towards ISIS, its fighters or its sympathisers.

From the discussion above it can be seen that both sets of examples draw on very different lexical sets to express affect and that there is, in these examples at least, little or no cross-over. For application to automated text analyses of features such as affect 
and sentiment it might prove to be productive to target selected lexical sets rather than to adopt a 'shotgun' type approach.

What these observations suggest is that taking a metafunctional approach to the meanings made through combinations of text and image in context is likely to be productive in developing strategies to distinguish between pro- and anti- extremist material on the internet and in identifying material with pro-extremist leanings. Furthermore, it is suggested that further exploring the interactions between the textual and interpersonal metafunctions in multimodal texts could be more productive than concentrating mainly on ideational meaning with limited interpersonal aspects (e.g. sentiment analysis), which is the major approach adopted in computer-based approaches to text and images analysis (e.g. natural language understanding and image processing). Likewise, analyses which examine the meanings arising from combinations of metafunctional choices in text and images could prove more productive than analyses which treat text and images in isolation.

\section{Notes:}

1 https://www.tineye.com/

2 The Long War Journal (https://www.longwarjournal.org/) is an American nonprofit news site which reports on the war on terror.

3 https://tomfernandez28.com/

4 https://www.businessinsider.com.au

5 http://www.dailymail.co.uk

\section{References}

Bateman J (2014) Looking for what counts in film analysis: a programme of empirical research. In Machin D (Ed) Visual Communication: 301-329 Berlin: De Gruyter Mouton. 
Halliday MAK (1978) Language as social semiotic. London: Edward Arnold.

Halliday M A K (1994) An introduction to functional grammar (2nd ed.). London: Arnold.

Halliday MAK and Matthiessen CMIM (2014) Halliday's introduction to functional grammar. London and New York: Routledge.

Kress G and van Leeuwen T (2006). Reading Images: The grammar of visual design (2nd ed.). London: Routledge.

Martin J R and Rose D (2003). Working with discourse: Meaning beyond the clause. London and New York: Continuum.

Martin J and Stenglin M (2007). Materialising reconciliation: Negotiating difference in a transcolonial exhibition. In Royce T and Bowcher W (eds), New directions in the analysis of multimodal discourse (pp. 215-238). Mahwah, NJ: Lawrence Erlbaum Associates.

Martinec R and Salway . (2005). A system for image-text relations in new (and old) media. Visual Communication 4(3): 337-371.

O’Halloran K Tan S, Wignell P and Lange R (2017 in press). Multimodal Recontextualisations of Images in Violent Extremist Discourse. In Zhao S, Djonov E, Björkvall A and Boeriis M (eds), The Art of Multimodality: Social Semiotic and Discourse Research in Honour of Theo van Leeuwen. New York and London: Routledge.

O’Halloran KL, Tan S and Wignell P (2016). Intersemiotic Translation as Resemiotisation: A Multimodal Perspective. Signata Annales des Semiotiques/Annals of Semiotics 7(2016).

O'Halloran KL, Tan S. and Wignell P (2017, in press). SFL and Multimodal Discourse Analysis. Ch 18 in Thompson G, Bowcher, WL, Fontaine L, Liang JY and Schontal D (eds). The Cambridge Handbook of Systemic Functional Linguistics. Cambridge: Cambridge University Press.

O’Halloran KL, Tan S, Wignell P, Bateman J, Pham D-S, Grossman M and Vande Moere A (2016). Interpreting Text and Image Relations in Violent Extremist Discourse: A Mixed Methods Approach for Big Data Analytics. Terrorism and Political Violence. doi.org/10.1080/09546553.2016.1233871

O'Toole M (2011). The language of displayed art (2nd ed.). London and New York: Routledge. 
Royce T (2007). Intersemiotic Complementarity: A Framework for Multimodal Discourse Analysis. In Royce, T. \& Bowcher, W. (eds), New Directions in the Analysis of Multimodal Discourse, 63-110. New Jersey and London: Lawrence Erlbaum Associates.

Royce T (2015). Intersemiotic complementarity in legal cartoons: An ideational multimodal analysis, International Journal for the Semiotics of Law - Revue internationale de Sémiotique juridique 01/2015. doi:10.1007/s11196-015-9421-1

Sahih Bukhari, Vol 4, Book 52, Number 73. https://www.sahihbukhari.com/Pages/Bukhari_4_52.php

Surah Al-Azhab 33:23. https://quran.com/33/23

Tan S, O’Halloran KL, Wignell P, Chai K and Lange R (2018). A Multimodal Mixed Methods Approach for Examining Recontextualisation Patterns of Violent Extremist Images in Online Media. Discourse, Context and Media, 21: 18-35 van Leeuwen T (2005). Introducing social semiotics. London: Routledge. Wignell P, Tan S and O'Halloran KL (2016). Violent Extremism and Iconisation: Commanding Good and Forbidding Evil? Critical Discourse Studies. doi: 10.1080/17405904.2016.1250652.

Wignell P, Tan S and O'Halloran KL (2017): Under the shade of AK47s: a multimodal approach to violent extremist recruitment strategies for foreign fighters, Critical Studies on Terrorism, doi: 10.1080/17539153.2017.1319319

Wignell P, Tan S, O’Halloran KL and Lange R (2017). A Mixed Methods Empirical Examination of Changes in Emphasis and Style in the Extremist Magazines Dabiq and Rumiyah. Perspectives on Terrorism, 11(2): 2-20.

Zelin AY (2015). Picture Or It Didn't Happen: A Snapshot of the Islamic State's Official Media Output. Perspectives on Terrorism, 9(4): 85-96. 